\title{
The effect of planting date on growth, seed stalk development and yield of sweet fennel
}

\author{
IRMA SUHONEN and LEENA KOKKONEN \\ Department of horticulture, University of Helsinki, SF-00710 Helsinki, Finland
}

\begin{abstract}
To study the growth and development of sweet fennel ('ZEFA-Fino' and 'ZEFATardo') seedlings were raised under greenhouse conditions (night temperature $16-18^{\circ} \mathrm{C}$ ) and planted out at 3-4 true leaf stage on May 21 st, June 10th, July 7 th and July 27 th. The effects of covering mulch and short day treatment of seedlings were studied also. First harvests were performed when field measurements showed that the greatest width of 'ZEFA-Fino' bulbs were on average $60 \mathrm{~mm}$. Three harvests were then performed at one week intervals. Plant and bulb weights, bulb greatest width and thickness and, the heights of plant, bulb and stem inside the bulb was measured. The number of bolters were recorded.

The bulb width of 'ZEFA-Fino' reached $60 \mathrm{~mm}$ in $1.5-2$ months after planting out depending on planting date. Plant and bulb weights, bulb width and thickness, stem height inside the bulb and the bulb height in the earliest plantings increased as the growth period lengthened. The bulb width of 'ZEFA-Fino' was in higher correlation with bulb weight than bulb thickness or height. The ratio between the height of stem inside the bulb and bulb height increased fastest in the lot planted under cover in May and in the lot planted out in June; at the fourth harvest the relationship was 0.8 . The largest number of bolters $(8 \%)$ was found in the latter lot. The yield estimate for 'ZEFA-Fino' at the third and fourth harvest was 170$360 \mathrm{~kg} / \mathrm{are}$ depending on planting date and length of the growing season.

All lots of 'ZEFA-Tardo' except that planted in July bolted quickly after the bulb width had grown to $60-70 \mathrm{~mm}$. The yield quality of 'ZEFA-Tardo' was low because of elongated bulbs and great variation in bulb height. Short day treatment (dark period $16 \mathrm{~h}$ ) of the seedlings retarded but did not inhibit bolting of 'ZEFA-Tardo'.
\end{abstract}

Index words: sweet fennel, planting date, growth, seedstalk development

\section{Introduction}

Sweet fennel (Foeniculum vulgare L. var. azoricum), an old vegetable in Mediterranean countries (MANSFELD 1986), is cultivated for late season and winter crop especially in Ita- ly, but also in other South European and some North African countries (Buishand \& JongE 1984, Vogel 1986). During the last few years an interest in growing sweet fennel has arisen 
in many Middle and North European countries where efforts have been made to find new varieties for outdoor vegetable production. Several sweet fennel cultivars have been in field tests also in Southern Finland, where the outdoor season lasts from May to September/October, the results, however, were not encouraging enough (SUHONEN 1970) to begin commercial production, but the Swiss cultivar Wädenswil was accepted by home gardeners.

In growing sweet fennel during spring and summer the main problem has been the quick development of seed stalk. As a consequence of this process the "bulb" (the tight bundle of swollen petiole bases) looses its tightness, crispness and commercial value too. Breeding of sweet fennel to diminish the sensitivity to bolting has been done especially in Switzerland, and a year around cultivar ZEFAFino was introduced in 1977 (KeLLER et al. 1977). According to field tests in Switzerland (Keller et al. 1977), in FRG (ANDRESEN \& Frenz 1981), in Denmark (HenriKsen 1982), in Norway (RygG \& RoEd 1986), in GDR (Vogel 1987) and in Finland (ANON. 1985) 'ZEFA-Fino' yields proper bulbs during spring and summer, but even then there can be many bolters (Vogel 1987) resulting in heavy loss of commercial sales.

To avoid the bolting losses during the cultivation of sweet fennel, exact information of seed stalk development would be useful, but the information in literature on this subject is limited. Thus experiments were designed to study the growth pattern, seed stalk development and yield of sweet fennel in early, middle and late season. In early season the effects of a covering mulch and a short day treatment of seedlings were also examined. The experiments were carried out on the test field at our Department in 1987.

\section{Materials and methods}

The cultivars in a series of five experiments were ZEFA-Fino and/or ZEFA-Tardo, a late season cultivar (Table 1). Growing recommendations given by KELLER et al. (1977) and by BuISHAND and JoNGE (1984) were adapted as follows. The young plants were raised in a greenhouse with night temperature between $16-18^{\circ} \mathrm{C}$. Seeds were sown in seedbeds on April 10th, May 5th, June 6th and June 26th. The seedlings at cotyledon stage were pricked into peat pots (FP 622) which were filled with fertilized peat. In experiment B two weeks short day treatment (dark period $16 \mathrm{~h}$ from 4 p.m. to 8 a.m.) after 6 days from pricking was given. The control plants were grown under natural long day.

Sweet fennels were planted out when they had 3-4 true leaves. Before planting (Table 1) plants were hardend outdoors for 3-4 days. The planting density was $45 \mathrm{~cm} \times 20 \mathrm{~cm}$. The soil of experimental plots was humous coarse silt with $\mathrm{pH}$ 6.8. As basic fertilization of $10 \mathrm{~kg} / 100 \mathrm{~m}^{2}$ a compound fertilizer (N $7 \%$, P $5 \%$, K $15 \%$ ) was given just before planting. Additional nitrogen fertilization with cal-

Table 1. Cultivars, sowing and planting dates, length of plant raising period and growing time on field until first harvest in experiments $\mathrm{A}, \mathrm{B}, \mathrm{C} 1, \mathrm{C} 2$ and $\mathrm{C} 3$.

\begin{tabular}{cccccc}
\hline Experiment & Cultivars & $\begin{array}{c}\text { Sowing } \\
\text { date }\end{array}$ & $\begin{array}{c}\text { Plant raising } \\
\text { (days) }\end{array}$ & $\begin{array}{c}\text { Planting } \\
\text { date }\end{array}$ & $\begin{array}{c}\text { Growing time } \\
\text { until first } \\
\text { harvest (days) }\end{array}$ \\
\hline A & ZEFA-Fino & Apr 10 & 41 & May 21 & 44 \\
B & ZEFA-Tardo & " & 41 & " & 44 \\
C1 & ZEFA-Fino & May 5 & 35 & & 43 \\
& ZEFA-Tardo & & & & \\
C2 & " & Jun 6 & 31 & Jul 7 & 45 \\
C3 & Jun 26 & 31 & Jul 27 & 56 \\
\hline
\end{tabular}


cium nitrate $\left(2 \mathrm{~kg} / 100 \mathrm{~m}^{2}\right)$ was performed when the petiole bases began to swell. During dry periods the experimental plots were irrigated. Weeds were controlled mechanically. During the growth period the plants were healthy and no treatments with posticides or fungicides were needed.

In experiment A Agryl P-17 sheet was used to study the effects of a covering mulch early in the season. The plants were covered just after planting out and sheet was taken off at the first harvest. The control plants remained uncovered.

First harvest (Table 1) was performed, when the test measurements from the field showed that the greatest width of 'ZEFA-Fino' bulbs were on average $60 \mathrm{~mm}$. The following three harvests were undertaken at one week intervals. At harvest the stem of sweet fennel was cut just beneath the bulb. The height and weight of rosettes were measured and the number of leaves were counted. The plants were then trimmed: sideshoots and loose outer leaves were removed, and the petioles of opened leaves were cut $5 \mathrm{~cm}$ over the swollen leaf base, only the innermost leaves which were shorter than $7 \mathrm{~cm}$ were left uncut. Trimmed bulbs were weighed individually and the greatest bulb width, height and thickness were recorded. The bulb was then split and the height of the stem inside the bulb was measured. If the seed stalk had already grown out of bulb, the plant was classified as a bolter. In estimating salable yield healthy proper bulbs weighing $100-450 \mathrm{~g}$ were included.

All experiments were arranged according to split plot design in quadruplicates. The averages presented in Tables 2-6 are means of 24 individual specimens, if no bolters were found. If bolting percentage was $50 \%$ or more, no averages were calculated.

\section{Results}

Covering mulch on the vegetation from end of May to beginning of July increased the growth of 'ZEFA-Fino' (Table 2). When the average bulb width in covering treatment was $60 \mathrm{~mm}$, the width of control bulbs was only $49 \mathrm{~mm}$. Also the bulb thickness and height were greater in the covering treatment. The average plant and bulb weights at first and second harvests in the covering treatment were $53-56 \%$ greater than the weights of control plants, but the relationship between bulb and plant weights were the same. The cover also accelerated the growth of stem inside the bulb, as well as the stem growth in relation to bulb height, however, only $0.5 \%$ of plants bolted. In the control there were no bolters. The cover especially increased the salable yield of first and second harvests.

'ZEFA-Tardo' plants grown under short day regime were less green after treatment and shorter $(24 \mathrm{~cm})$ at the end of plant raising period than the control plants $(30 \mathrm{~cm})$, but both had 4 opened true leaves on average. At the first harvest the short day treated plants were higher $(47 \mathrm{~cm})$ and heavier $(104 \mathrm{~g})$, and they had less true leaves (8.1) than the control plants ( $42 \mathrm{~cm}, 94 \mathrm{~g}, 9.9$ true leaves). The treatment retarded the number of bolters and the growth of stem inside the bulb (Table 3), but it was not effective enough to ensure a proper yield. When the average bulb weight of the short day treated plants was $100 \mathrm{~g}$, there were already $17 \%$ bolters in the stand and a week later the bolting percentage was $70 \%$.

The bulb width of 'ZEFA-Fino' planted on June 10th and on July 7 th reached $60 \mathrm{~mm}$ after 1.5 months growth in the field, but the last planting lot needed about 10 days more to reach the same stage (Table 4). The growth of bulb width of 'ZEFA-Tardo' was slightly slower (Table 5).

The bolting percentage of 'ZEFA-Tardo' was very high in lots planted out on June 10th and July 7 th (Table 5), and even in the last group there were nearly $50 \%$ bolters at the time of the fourth harvest. Bolters in 'ZEFAFino' were found only at the fourth harvest in the lots planted out on June 10th (8\%) and on July 7 th (4\%), where the effective tem- 
Table 2. The effect of covering mulch and harvesting time on the growth of 'ZEFA-Fino' planted May 21st (experiment A). First harvest 44 days (July 34rd) after planting out, subsequent harvests at one week intervals.

\begin{tabular}{|c|c|c|c|c|c|c|}
\hline & \multicolumn{6}{|c|}{ Harvest } \\
\hline & Treatment ${ }^{x}$ & 1 & 2 & 3 & 4 & Meany \\
\hline Bulb width mm & $\begin{array}{l}\mathrm{M} \\
\mathrm{C}\end{array}$ & $\begin{array}{l}60 \\
49\end{array}$ & $\begin{array}{l}80 \\
64\end{array}$ & $\begin{array}{l}82 \\
79\end{array}$ & $\begin{array}{r}102 \\
84\end{array}$ & $\begin{array}{l}81 * * \\
69\end{array}$ \\
\hline $\begin{array}{l}\text { Number of true } \\
\text { leaves }\end{array}$ & $\begin{array}{l}\mathrm{M} \\
\mathrm{C}\end{array}$ & $\begin{array}{l}8.1 \\
7.3\end{array}$ & $\begin{array}{l}9.0 \\
8.0\end{array}$ & $\begin{array}{l}9.3 \\
9.3\end{array}$ & $\begin{array}{l}10.8 \\
10.1\end{array}$ & $\begin{array}{l}9.3 \mathrm{n} .5 . \\
8.7\end{array}$ \\
\hline Plant height $\mathrm{cm}$ & $\begin{array}{l}\mathrm{M} \\
\mathrm{C}\end{array}$ & $\begin{array}{l}61 \\
48\end{array}$ & $\begin{array}{l}65 \\
56\end{array}$ & $\begin{array}{l}64 \\
59\end{array}$ & $\begin{array}{l}61 \\
54\end{array}$ & $\begin{array}{l}63^{*} \\
54\end{array}$ \\
\hline Plant weight $g$ (A) & $\begin{array}{l}\mathrm{M} \\
\mathrm{C}\end{array}$ & $\begin{array}{l}176 \\
113\end{array}$ & $\begin{array}{l}313 \\
205\end{array}$ & $\begin{array}{l}355 \\
307\end{array}$ & $\begin{array}{l}504 \\
368\end{array}$ & $\begin{array}{l}337^{*} \\
248\end{array}$ \\
\hline Bulb weight g (B) & $\begin{array}{l}\mathrm{M} \\
\mathrm{C}\end{array}$ & $\begin{array}{l}84 \\
54\end{array}$ & $\begin{array}{r}153 \\
98\end{array}$ & $\begin{array}{l}185 \\
159\end{array}$ & $\begin{array}{l}276 \\
196\end{array}$ & $\begin{array}{l}175^{* *} \\
127\end{array}$ \\
\hline Relation B/A & $\begin{array}{l}\mathrm{M} \\
\mathrm{C}\end{array}$ & $\begin{array}{l}0.48 \\
0.48\end{array}$ & $\begin{array}{l}0.49 \\
0.48\end{array}$ & $\begin{array}{l}0.52 \\
0.52\end{array}$ & $\begin{array}{l}0.55 \\
0.53\end{array}$ & $\begin{array}{l}0.51 \\
0.50\end{array}$ \\
\hline Bulb thickness mm & $\begin{array}{l}\mathrm{M} \\
\mathrm{C}\end{array}$ & $\begin{array}{l}31 \\
27\end{array}$ & $\begin{array}{l}43 \\
35\end{array}$ & $\begin{array}{l}45 \\
44\end{array}$ & $\begin{array}{l}51 \\
47\end{array}$ & $\begin{array}{l}43^{* * *} \\
38\end{array}$ \\
\hline Bulb height mm (C) & $\begin{array}{l}\mathrm{M} \\
\mathrm{C}\end{array}$ & $\begin{array}{l}82 \\
73\end{array}$ & $\begin{array}{l}93 \\
84\end{array}$ & $\begin{array}{r}100 \\
92\end{array}$ & $\begin{array}{l}120 \\
105\end{array}$ & $\begin{array}{l}99 * * \\
89\end{array}$ \\
\hline $\begin{array}{l}\text { Stem height inside } \\
\text { bulb mm (D) }\end{array}$ & $\begin{array}{l}\mathrm{M} \\
\mathrm{C}\end{array}$ & $\begin{array}{l}35 \\
31\end{array}$ & $\begin{array}{l}53 \\
43\end{array}$ & $\begin{array}{l}62 \\
55\end{array}$ & $\begin{array}{l}99 \\
78\end{array}$ & $\begin{array}{l}62 * \\
52\end{array}$ \\
\hline Relation D/C & $\begin{array}{l}\mathrm{M} \\
\mathrm{C}\end{array}$ & $\begin{array}{l}0.44 \\
0.43\end{array}$ & $\begin{array}{l}0.57 \\
0.51\end{array}$ & $\begin{array}{l}0.63 \\
0.60\end{array}$ & $\begin{array}{l}0.81 \\
0.74\end{array}$ & $\begin{array}{l}0.61 \\
0.57\end{array}$ \\
\hline $\begin{array}{l}\text { Salable yield } \\
\mathrm{kg} / 100 \mathrm{~m}^{2}\end{array}$ & $\begin{array}{l}\mathrm{M} \\
\mathrm{C}\end{array}$ & $\begin{array}{r}32 \\
0\end{array}$ & $\begin{array}{r}165 \\
69\end{array}$ & $\begin{array}{l}199 \\
166\end{array}$ & $\begin{array}{l}280 \\
216\end{array}$ & $\begin{array}{l}169^{* *} \\
113\end{array}$ \\
\hline
\end{tabular}

$\times \mathbf{M}=$ mulch, $\mathrm{C}=$ control

$y$ and significance of differences between means of M and C, Tukey's test.

Table 3. Effect of short day treatment during plant raising and of harvesting time on bolting and on properties of non-bolted bulbs of 'ZEFA-Tardo' planted out May 21st (experiment B). First harvest 44 days (July 3rd) after planting out, subsequent harvests at one week intervals.

\begin{tabular}{|c|c|c|c|c|c|c|c|}
\hline \multirow[t]{2}{*}{ Treatment } & \multirow[t]{2}{*}{ Harvest } & \multicolumn{6}{|c|}{ Non-bolted bulbs } \\
\hline & & $\begin{array}{c}\text { Bolting } \\
\%\end{array}$ & $\begin{array}{l}\text { Width } \\
\text { mm }\end{array}$ & $\begin{array}{c}\text { Weight } \\
\mathrm{g}\end{array}$ & $\begin{array}{l}\text { Height } \\
\text { mm (A) }\end{array}$ & $\begin{array}{c}\text { Stem height } \\
\text { mm (B) }\end{array}$ & $\begin{array}{c}\text { Relation } \\
\text { B/A }\end{array}$ \\
\hline Natural & 1 & 4 & 45 & 45 & 76 & 47 & 0.61 \\
\hline \multirow[t]{3}{*}{ long day } & 2 & 46 & 55 & 70 & 91 & 64 & 0.71 \\
\hline & 3 & 78 & - & - & - & - & - \\
\hline & 4 & 100 & - & - & - & - & - \\
\hline \multirow[t]{4}{*}{ Short day } & 1 & 0 & 45 & 50 & 78 & 33 & 0.42 \\
\hline & 2 & 0 & 58 & 77 & 89 & 52 & 0.58 \\
\hline & 3 & 17 & 63 & 107 & 102 & 73 & 0.71 \\
\hline & 4 & 70 & - & - & - & - & - \\
\hline
\end{tabular}

perature sums were $595^{\circ} \mathrm{C}$ and $546^{\circ} \mathrm{C}$ respectively (Figure 1).

In the last planting, 'ZEFA-Fino' plants had less true leaves than in the earlier lots, but they were above average in height (Table 4).
The width and the stem height inside the bulb, and also the thickness of 'ZEFA-Fino' bulbs increased with a longer growing period, but the increase in bulb height was significant only for the lot planted out in June (Table 4). The 
Table 4. The effect of planting date and harvesting time on number of true leaves, plant height and on properties of bulbs of 'ZEFA-Fino'. First harvest 43 days (planted June 10th, experiment C1), 45 days (planted July 7th, experiment $\mathrm{C2}$ ) and 56 days (planted July 27th, experiment C3) after planting out, subsequent harvests at one week intervals.

\begin{tabular}{|c|c|c|c|c|}
\hline & \multirow[t]{2}{*}{ Harvest } & \multicolumn{3}{|c|}{ Planting date } \\
\hline & & June 10th ${ }^{x}$ & July 7 th $^{x}$ & July 27 th $^{x}$ \\
\hline Bulb width $\mathrm{mm}$ & $\begin{array}{l}1 \\
2 \\
3 \\
4\end{array}$ & $\begin{array}{l}62 a \\
75 b \\
93 c \\
98 c\end{array}$ & $\begin{array}{l}71 \mathrm{a} \\
80 \mathrm{ab} \\
87 \mathrm{c} \\
96 \mathrm{~cd}\end{array}$ & $\begin{array}{l}69 a \\
75 a b \\
79 b \\
77 b\end{array}$ \\
\hline Number of true leaves & $\begin{array}{l}1 \\
2 \\
3 \\
4\end{array}$ & $\begin{array}{r}8.1 \mathrm{a} \\
8.9 \mathrm{~b} \\
11.0 \mathrm{c} \\
11.4 \mathrm{c}\end{array}$ & $\begin{array}{l}8.4 \mathrm{a} \\
8.6 \mathrm{a} \\
9.0 \mathrm{a} \\
9.1 \mathrm{a}\end{array}$ & $\begin{array}{l}7.7 \mathrm{a} \\
7.5 \mathrm{a} \\
7.3 \mathrm{a} \\
7.7 \mathrm{a}\end{array}$ \\
\hline Plant height $\mathrm{cm}$ & $\begin{array}{l}1 \\
2 \\
3 \\
4\end{array}$ & $\begin{array}{l}57 a \\
64 a \\
65 a \\
64 a\end{array}$ & $\begin{array}{c}68 a \\
69 a \\
69 a \\
68 a\end{array}$ & $\begin{array}{l}70 a \\
72 a \\
71 a \\
70 a\end{array}$ \\
\hline Bulb thickness mm & $\begin{array}{l}1 \\
2 \\
3 \\
4\end{array}$ & $\begin{array}{l}36 \mathrm{a} \\
41 \mathrm{a} \\
52 \mathrm{~b} \\
55 \mathrm{~b}\end{array}$ & $\begin{array}{l}42 \mathrm{a} \\
52 \mathrm{~b} \\
55 \mathrm{~b} \\
59 \mathrm{~b}\end{array}$ & $\begin{array}{l}42 a \\
44 a \\
45 a \\
48 a\end{array}$ \\
\hline Bulb height mm (A) & $\begin{array}{l}1 \\
2 \\
3 \\
4\end{array}$ & $\begin{array}{c}84 \mathrm{a} \\
95 \mathrm{ab} \\
107 \mathrm{bc} \\
126 \mathrm{c}\end{array}$ & $\begin{array}{l}104 a \\
100 a \\
107 a \\
103 a\end{array}$ & $\begin{array}{r}95 a \\
102 a \\
107 a \\
101 a\end{array}$ \\
\hline $\begin{array}{l}\text { Stem height inside } \\
\text { bulb mm (B) }\end{array}$ & $\begin{array}{l}1 \\
2 \\
3 \\
4\end{array}$ & $\begin{array}{l}36 \mathrm{a} \\
53 \mathrm{~b} \\
73 \mathrm{c} \\
98 \mathrm{~d}\end{array}$ & $\begin{array}{l}42 a \\
52 b \\
64 c \\
79 d\end{array}$ & $\begin{array}{l}43 a \\
47 b \\
46 b \\
52 c\end{array}$ \\
\hline Relation $\mathrm{B} / \mathrm{A}$ & $\begin{array}{l}1 \\
2 \\
3 \\
4\end{array}$ & $\begin{array}{l}0.42 \\
0.55 \\
0.68 \\
0.77\end{array}$ & $\begin{array}{l}0.40 \\
0.52 \\
0.59 \\
0.76\end{array}$ & $\begin{array}{l}0.45 \\
0.46 \\
0.42 \\
0.51\end{array}$ \\
\hline
\end{tabular}

*Values followed by same letter are not significantly different at $\mathrm{P}=0.05$ by Tukey's test.

increases in average plant and bulb weights between harvests were notable especially in the lot planted out on June 10th (Figure 1). The relationship between bulb weight and plant weight varied from 0.47 to 0.62 . This ratio was lowest at the time of the first harvests. The highest ratio was obtained for the lot planted on June 10th at the last harvest. The growth of bulbs in the last planting lot was very slow after the first harvest, but there still was significant increase in bulb weight $(73 \mathrm{~g})$ between first and fourth harvest. The increase in effective temperature sum between those harvests was only $46^{\circ} \mathrm{C}$.

The salable yield of 'ZEFA-Fino' increased with a lengthening of the growing period, and the greatest salable yields were achieved from stands planted out on June 10th and on July 7 th (Figure 1). The yield of 'ZEFA-Tardo' was low because of bolters, and the yield quality was also poor, because of elongated bulbs and great variation in bulb heights especially for the last planting lot (Table 5).

In bulbs of 'ZEFA-Fino' there were significant correlations between bulb weight vs bulb greatest width, greatest thickness and height in all experiments (Table 6). The best correlation coefficients were between weight vs width. Using the average values of bulb width and bulb weight presented in Tables 2 and 4 
Table 5. The effect of planting date and harvesting time on bolting and on properties of non-bolted bulbs of 'ZEFA-Tardo'. First harvests 43 days (planted June 10th), 45 days (planted July 7 th) and 56 days (planted July 27 th) after planting out, subsequent harvests at one week intervals.

\begin{tabular}{|c|c|c|c|c|c|}
\hline & \multirow[t]{3}{*}{ Harvest } & \multicolumn{4}{|c|}{ Planting date } \\
\hline & & \multirow[t]{2}{*}{ June 10th } & \multirow[t]{2}{*}{ July 7 th } & \multicolumn{2}{|c|}{ July 27 th $^{x}$} \\
\hline & & & & mean & variation \\
\hline Bolting $\%$ & $\begin{array}{l}1 \\
2 \\
3 \\
4\end{array}$ & $\begin{array}{l}21 \\
46 \\
92 \\
92\end{array}$ & $\begin{array}{l}29 \\
42 \\
54 \\
67\end{array}$ & $\begin{array}{r}0 \\
4 \\
17 \\
44\end{array}$ & \\
\hline Bulb width $\mathrm{mm}$ & $\begin{array}{l}1 \\
2 \\
3 \\
4\end{array}$ & $\begin{array}{c}59 \\
(67) \\
- \\
-\end{array}$ & $\begin{array}{c}66 \\
(76) \\
- \\
-\end{array}$ & $\begin{array}{r}63 \mathrm{a} \\
74 \mathrm{~b} \\
73 \mathrm{~b} \\
(72)\end{array}$ & \\
\hline Bulb weight $g$ & $\begin{array}{l}1 \\
2 \\
3 \\
4\end{array}$ & $\begin{array}{c}78 \\
(128) \\
- \\
-\end{array}$ & $\begin{array}{c}127 \\
(197) \\
- \\
-\end{array}$ & $\begin{array}{l}116 \mathrm{a} \\
161 \mathrm{~b} \\
174 \mathrm{~b} \\
(181)\end{array}$ & \\
\hline $\begin{array}{l}\text { Bulb height }{ }^{y} \\
\text { mm (A) }\end{array}$ & $\begin{array}{l}1 \\
2 \\
3 \\
4\end{array}$ & $\begin{array}{c}101 \\
(138) \\
- \\
-\end{array}$ & $\begin{array}{c}119 \\
(151) \\
- \\
-\end{array}$ & $\begin{array}{r}118 \mathrm{a} \\
130 \mathrm{a} \\
131 \mathrm{a} \\
(148)\end{array}$ & $\begin{array}{l}95-180 \\
90-190 \\
95-210\end{array}$ \\
\hline $\begin{array}{l}\text { Stem height }{ }^{y} \text { inside } \\
\text { bulb mm (B) }\end{array}$ & $\begin{array}{l}1 \\
2 \\
3 \\
4\end{array}$ & $\begin{array}{c}74 \\
(115) \\
- \\
-\end{array}$ & $\begin{array}{c}72 \\
(113) \\
- \\
-\end{array}$ & $\begin{array}{r}71 \mathrm{a} \\
83 \mathrm{a} \\
88 \mathrm{a} \\
(113)\end{array}$ & $\begin{array}{l}38-115 \\
40-180 \\
55-185\end{array}$ \\
\hline Relation B/A & $\begin{array}{l}1 \\
2 \\
3 \\
4\end{array}$ & $\begin{array}{c}0.73 \\
(0.83) \\
- \\
-\end{array}$ & $\begin{array}{c}0.60 \\
(0.74) \\
- \\
-\end{array}$ & $\begin{array}{c}0.60 \\
0.71 \\
0.67 \\
(0.76)\end{array}$ & \\
\hline
\end{tabular}

× Values followed by same letter are not significantly different at $\mathrm{P}=0.05$ by Tukey's test.

y Great variation between individuals specially in the last planting lot, limits are given in the table.

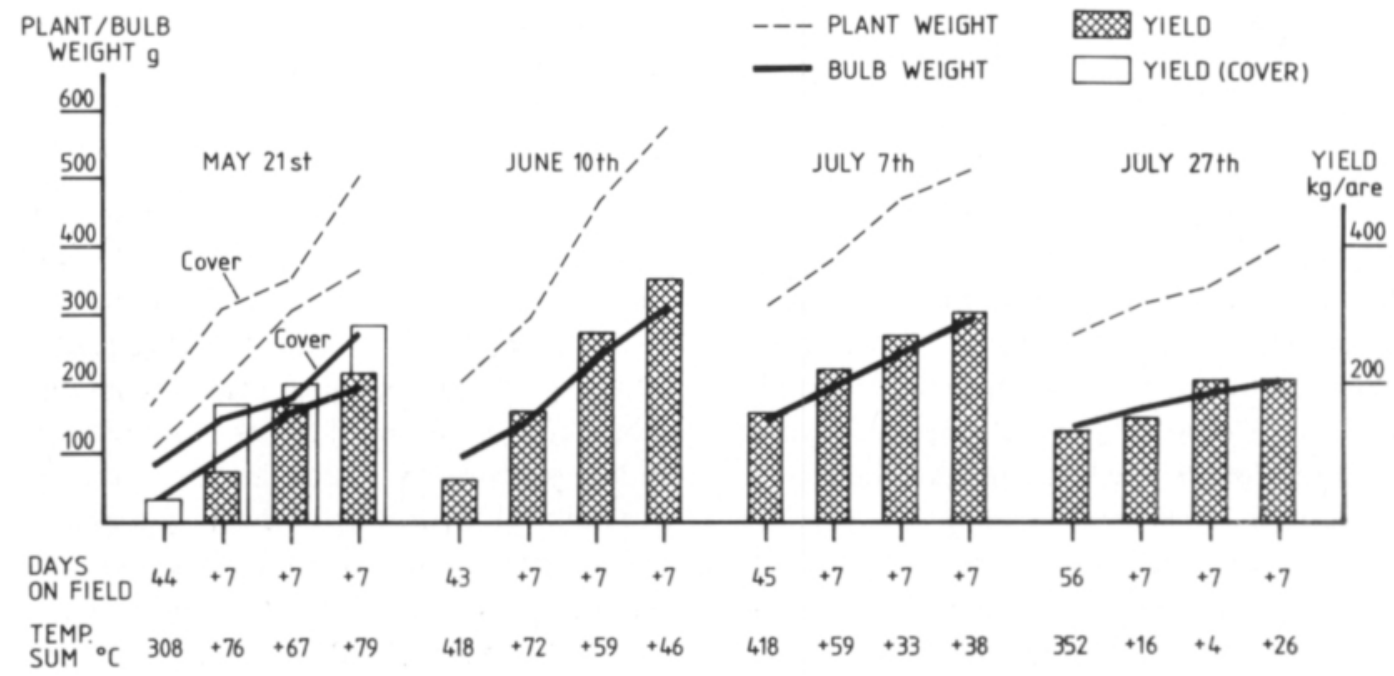

Fig. 1. Plant and bulb weights and estimated salable yield of 'ZEFA-Fino' at harvests 1 to 4 in experiment A (planted May 21st) and in experiments C1, C2 and C3 (planted June 10th, July 7th and July 27th).

Temp. sum $=$ the sum of effective day degrees over $5^{\circ} \mathrm{C}$ 
Table 6. Correlations between bulb weight and bulb width, thickness and height of 'ZEFA-Fino' in experiments $\mathrm{A}, \mathrm{C} 1, \mathrm{C} 2$ and $\mathrm{C} 3$.

\begin{tabular}{llll}
\hline Experiment & \multicolumn{3}{c}{ Weight vs } \\
\cline { 2 - 4 } & width & thickness & height \\
\hline A (cover) & $0.94^{* * *}$ & $0.84^{* * *}$ & $0.62^{* * *}$ \\
A (control) & $0.95^{* * *}$ & $0.91^{* * *}$ & $0.64^{* * *}$ \\
C 1 & $0.91^{* * *}$ & $0.85^{* * *}$ & $0.65^{* * *}$ \\
C 2 & $0.93^{* * *}$ & $0.81^{* * *}$ & $0.24^{*}$ \\
C 3 & $0.87^{* * *}$ & $0.81^{* * *}$ & $0.33^{* *}$ \\
\hline
\end{tabular}

${ }^{*} \mathrm{P}<0.05,{ }^{* *} \mathrm{P}<0.01,{ }^{* * *} \mathrm{P}<0.001$

and in Figure 1, it can be estimated that the bulb size of $100 \mathrm{~g}$ was reached when the bulb width was about $64 \mathrm{~mm}$ and $200 \mathrm{~g}$ when bulb width was about $82 \mathrm{~mm}$.

\section{Discussion}

The test cultivars behaved themselves very differently under the prevailing circumstances. 'ZEFA-Tardo' proved to be a quick bolter in spring and in summer as was to be expected, but there was also plenty of bolters in autumn, when it should have yielded proper bulbs. Our results with 'ZEFA-Tardo' are in agreement with the Danish results (HENRIKSEN 1982), but differ from the Dutch results, which showed no bolters in late season cultivation (Buishand \& Jonge 1984). Short day treatment during seedling phase retarded, but did not inhibit the development of seed stalk of 'ZEFA-Tardo', which agrees with a similar experiment in Denmark (Henriksen 1982). The non-bolted individuals of 'ZEFA-Tardo' gave small bulbs weighing under $200 \mathrm{~g}$, which had relatively long stem inside the bulb.

In contrast to 'ZEFA-Tardo' bolters were only found with 'ZEFA-Fino' when the harvest was 2 months after planting out. In sowing and planting time experiments carried out in Switzerland, the bolting of 'ZEFA-Fino' after about 2 months growing time under field conditions was under $1 \%$, except in one lot planted out in beginning of July (KELLER et al. 1977). In the Danish experiments there were $1-15 \%$ bolters after two months growing time under field conditions, and after
70 days the percentage of bolters was $37 \%$ in a lot planted out at the end of June (HEN. RIKSEN 1982). In field tests made in GDR the number of bolters in 'ZEFA-Fino' after about two months growing time was usually high, often over $20 \%$. It was stated that the speed of bolting depends on weather, and in stands planted out during June or during the two first weeks of July a high percentage of bolting can be expected (VoGEL 1987). In our tests with 'ZEFA-Fino' the tendency was the same; during warmest periods of weather, and under cover the growth of stem inside the bulb was fastest, and some individuals bolted.

The field measurements of bulb width of 'ZEFA-Fino' to forecast the average bulb width in yield gave good correlations in experiments $\mathrm{A}$ and $\mathrm{C} 1$, but not as good in experiments $\mathrm{C} 2$ and $\mathrm{C} 3$, where the first harvests were delayed. Obviously there were too long intervals between field measurements. According to our results, the bulb width of 'ZEFA-Fino' is highly correlated to bulb weight, and it is better forecaster for yield than bulb height or thickness. In foretelling the development of seed stalk the measurement of stem length inside the bulb seems to be a good parameter. Our observations indicate, that the relation 0.7 between stem height inside the bulb and bulb height will predict that in warm weather 'ZEFA-Tardo' is likely to bolt. In 'ZEFA-Fino' the same stem/bulb height relation did not give a high number of bolters under the test conditions. A warmer period at this stage could alter the behavior of this cultivar, thus further tests are required.

In our experiments the number of individuals was insufficient for giving an exact prognosis of salable yields. The estimates, howev$\mathrm{er}$, indicate, that a yield level of $200-300 \mathrm{~kg} /$ are for 'ZEFA-Fino' can be reached in 2-2.5 months growing time under field conditions, if young plants are raised beforehand in a hot house and the weight of $100 \mathrm{~g}$ per bulb is approved as the lower limit. The leaf yield will be nearly the same as the bulb yield, or slightly smaller with the swelling of bulbs. 
According to our observations 'ZEFAFino' benefits from a covering sheet early in the season. If $200 \mathrm{~kg} / \mathrm{are}$ is the target for yield, the covered stand was about a week earlier than the uncovered one. In tests of ANDRESEN and Frenz (1981) the growing time of 'ZEFA-Fino' was reduced by nine days, when a perforated plastic cover was kept on a stand planted out in April for five weeks. If the cover is kept on sweet fennel for too long a time, then the bulb weight can be reduced (BUISHAND \& JONGE 1984).

\section{References}

Andresen, F. \& Frenz, F.W. 1981. Der Einfluss des Saattermins auf das Schossen und den Ertrag von Knollenfenchel-Sorten. Gemüse 17: 162-168.

ANON. 1985. Kirjallinen tieto. Finska Hushállningssällskapet. Turku.

Buishand, T. \& de Jonge, P. 1984. Teelt van knolvenkel. Teelthandleiding nr. 16. 39 p. Lelystad.

Henriksen, K. 1982. Dyrking af knoldfennikel. Stat. Planteavlforsog. Medd. 1677. 4 p.

Keller, F., Stengel, E., Todt, W. Wixinger, K. 1977. Anbau und Vermarktung von Knollenfenchel in der Schweiz. 55 p. Schweizerische Gemüse-Union. Zürich. MANSFELD, R. 1985. Verzeichnis landwirtschaftlicher und gärtnerischer Kulturpflanzen 2. p. 1014-1018. Springer-Verlag. Berlin etc.

RygG, M. \& Røed, U. 1986. Semesteroppgave 1 GD 2 1986. Norges Landbrugshøgskule, Ảs, Norge.

SUHONEn, I. 1970. Kylvöajan vaikutuksesta salaattivenkolin kehitykseen. Puutarha 73: 262-265.

VoGEL, G. 1986. Knollenfenchel, eine schnellwachsende Gemüseart, die den Staffelanbau ermöglicht. Gartenb. 33: 116-119.

- 1987. Zum Einfluss gestaffelter Planztermine und unterschiedlicher Standweiten auf die Ertragsleistung von Knollenfenchel. Arch. Gartenb. 35(1): 1-11.

Ms received September 25, 1989

\section{SELOSTUS}

\section{Istutusajan vaikutus salaattifenkolin kasvuun ja kehittymiseen}

\section{Irma Suhonen ja Leena Kokkonen \\ Helsingin yliopiston puutarhatieteen laitos, Viikki, 00710 Helsinki}

Kasvihuoneessa esikasvatetun ja kolmi-nelilehtiasteella avomaalle istutetun salaattifenkolin ('ZEFA-Fino' ja 'ZEFA-Tardo') kasvua ja kehittymistä tutkittiin v. 1987 viiden kokeen koesarjassa. Ensimmäiset erät istutettiin 21.5. ja viimeinen 27.7. Aikaisten erien viljelyssă selvitettiin myös harsokatteen ja taimien lyhytpäiväkäsittelyn (pimeăjakso 16 h) merkitystä.

Kokeissa sato korjattiin ensimmäisen kerran, kun 'ZEFA-Finon' lehtikantakimpun, "mukulan", suurin leveys oli kenttămittausten mukaan $60 \mathrm{~mm}$. Seuraavat 3 korjuuta tapahtuivat viikon vălein. Kasvin korkeus ja paino, mukulan paino, korkeus, suurin leveys ja paksuus, mukulan sisässă olevan varren pituus sekä kukkavarren esiinkasvu määritettiin yksilömittauksin.

'ZEFA-Finon' mukulat saavuttivat $60 \mathrm{~mm}$ : $\mathrm{n}$ leveyden 1,5-2 kuukaudessa istutuksesta lukien. Kasvuajan pidetessä yksilöpaino ja mukulan paino, leveys, paksuus sekả korkeus kasvoivat, ja mukulan sisăssä oleva varsi piteni. 'ZEFA-Finon' mukuloiden suurimman leveyden ja painon välinen korrelaatiokerroin oli $0,87-0,95$ kokeesta riippuen. Suurimman leveyden ollessa n. $64 \mathrm{~mm}$ mukulat painoivat keskimäärin $100 \mathrm{~g}$, ja keskimäärin $200 \mathrm{~g}$, kun suurin leveys oli n. $82 \mathrm{~mm}$. Toukokuun loppupuolella istutetun 'ZEFA-Finon' sato aikaistui noin viikon harsokatteen ansiosta.

Molemmissa lajikkeissa mukulan sisässä olevan varren pituuden suhde mukulan korkeuteen suureni kasvuajan pidetessă. Kesăkuun 10. päivănă istutetulla 'ZEFA-Finolla' tämă suhde kasvoi neljänteen korjuukertaan mennessă 0,8 :aan, ja tăllöin esiintyi eniten $(8 \%)$ yksilöită, joiden kukkavarsi oli kasvamassa tai kasvanut esiin mukulasta. Muutoin tällă lajikkeella kukkavarren esiinkasvua oli văhăn. 'ZEFA-Tardolla' kukkavarren kasvu oli yleensă niin nopeaa, ettei kauppakelpoista satoa juuri saatu. Heinăkuun lopussa istutettu erä kehitti kukkavarsia muita hitaammin, mutta siinäkin sato oli heikkolaatuista. Lyhytpăivăkăsittely taimivaiheessa hidasti, mutta ei estänyt 'ZEFA-Tardon' kukkavarren kasvua. 